\title{
Cultural Policy and Cultural Politics in Revolutionary Cuba: Re-reading the Palabras a los intelectuales (Words to the Intellectuals)
}

\author{
PAR KUMARASWAMI \\ University of Manchester, UK
}

This article re-reads Fidel Castro's speech to Cuban artists and intellectuals at the Biblioteca Nacional José Martí (National Library) in June 1961. Despite extensive discussion of its famous extract, the speech has rarely been examined in depth. This article thus analyses the entire speech, situating it within its co-text and its context and examining its multiple functions, offering as it does an insight into the social and educational implications of cultural revolution in Cuba and the inevitable tensions inherent in these. The article evaluates the negotiations in the text in the light of their relevance to contemporary cultural debates in Cuba.

Keywords: Castro, Cuba, cultural democratisation, intellectuals, revolution.

\section{Perspectives and Contexts}

This article seeks to re-read Fidel Castro's speech delivered at the Biblioteca Nacional José Martí in June 1961. ${ }^{1}$ The centrality of the Palabras as a policy document has been reinforced on countless occasions, both on and off the island, to support a range of positions: either to demonstrate the supposedly authoritarian hold that Castro maintained until his recent retirement over all aspects of life in Cuba, including freedom of artistic expression; to underline the swift and inevitable alignment after 1959 of the Cuban revolutionary leadership with Stalinist/Zhadanovian cultural doctrine, that

1 The text of the speech was first published by the Consejo Nacional de Cultura (National Cultural Council) soon after its creation in January 1961 (Castro, 1961a). It is also available online in its original Spanish version (Castro, 1961b) and in a reasonably good English translation (Castro, 1961c). All references in this article are to the online Spanish version of the speech (1961b), and all translations into English are the responsibility of the author. 
is, to demonstrate the 'sovietisation' of Cuban culture after 1959; or, conversely, to celebrate the logic, coherence and continuity of cultural policy over the nearly 50 years of the Revolution. ${ }^{2}$ Importantly, however, its ambiguity, polivocality and complexity have very often been reduced to its most famous (and sometimes misquoted) extract, thus precluding a comprehensive view of the speech's multiple functions: 'Dentro de la Revolución, todo; contra la Revolución, nada' ('Within the Revolution, everything; against the Revolution, nothing'). ${ }^{3}$ In terms of cultural politics rather than cultural policy, the speech has also been interpreted as an important position paper delivered to alleviate a situation of growing confusion and suspicion between leading figures in the newly formed Consejo Nacional de Cultura (CNC), created under Armando Hart Dávalos's Ministerio de Educación (Ministry of Education) in January 1961, and a significant number of Havana-based artists and intellectuals, prompted by the controversial events surrounding the production and reception of the documentary film $P M$ in May 1961 and further aggravated by the subsequent closing of the cultural supplement of the Movimiento Revolucionario (MR-26) newspaper Revolución, Lunes de Revolución, in November 1961. It has been viewed in the light of the immediate overlapping of the worlds of politics and letters occasioned by the nomination of trusted leading figures in the MR-26 and Ejército Rebelde (Rebel Army) to positions of leadership in the cultural scene: in other words, it has been seen as an early signal of the backing of political figures over their cultural counterparts and, thus, of the prioritisation of ideology and politics over 'free' cultural expression.

What has been lacking in observations on the Palabras, however, is a more holistic and detailed analysis of the entire text itself, rather than its use to support a priori positions vis à vis the Revolution. This article therefore seeks to go beyond the sometimes polarised and simplified interpretations of the single extract 'Dentro/Contra', not only to situate the extract within its co-text and its context, but also to explore the speech in its entirety, and thus aims to examine its multiple functions within the context of its delivery. Hence, a significant part of the article is dedicated to an analytical summary from a contemporary perspective of the principal policy aspects outlined by Castro, many of which have been overlooked or neglected, and without an understanding of which it is easy to distort the speech. The article then further explores some of the clear tensions and ambiguities, the cultural politics, apparent in Castro's speech. It concludes by considering the text not simply as top-down cultural policy, as an ultimatum or decree from above to be followed to the letter, not as an exclusivist dictum along the lines of 'Dentro/Fuera'; but rather, as an early example of the complex cultural policies and politics that have characterised the entire trajectory of culture and revolution in Cuba. ${ }^{4}$

2 Amongst the innumerable references to the speech in academic and journalistic sources, there are more sustained analyses of its contents in Casal (1971), Weiss (1985), Dopico Black (1989), Franco (2002), Kapcia (2005) and, more recently, of its relevance to the concept of the 'New Man' in Serra (2007).

3 The extract is also regularly read as 'Dentro/Fuera' ('Within/Outside'), most notably by Weiss (1985: 121) and Franco (2002: 89), contributing to its continued interpretation as evidence of repression.

4 Very recent and contemporary cultural debates now focus on the reappraisal of cultural policy and practice in the 1960s and 1970s: see Pogolotti (2006); the 'Encuentros' (Meetings) collected in La Politica Cultural del Período Revolucionario (2007); Abreu Arcia (2007). 
As many Cuban commentators have recently outlined, of much greater significance than the tense cultural climate in which the meetings took place is the urgent political and social situation in that chaotic, iconic and euphoric year of 1961: the rupture of US-Cuban relations; the attempted counter-revolution in the Escambray mountains; the launch of the Literacy Campaign on 1 January, with constant updates in the daily press as to its rapid success; the declaration by Castro of the socialist nature of the Revolution on 16 April; the rapid and triumphant defeat of the US-backed invasion at Playa Girón between 17 and 20 April; the law nationalising education passed on 6 June; the visit of Khrushchev to Cuba in June; the increasing US embargo on foodstuffs; and the end of the Literacy Campaign in December 1961. Ambrosio Fornet describes the backdrop to the Palabras in June 1961 in the following way:

[E]1 ... discurso se pronunció el 30 de junio de 1961, apenas dos meses después de Playa Girón .... Las Palabras a los intelectuales hallaron su tono y su caja de resonancia natural en el clima político de la época, caldeado por la indignación contra los yanquis, el orgullo de la victoria y la exaltación nacionalista.

([T]he speech was delivered on 30 June 1961, barely two months after the Bay of Pigs .... The Words to the Intellectuals found their tone and their soundbox in the political climate of the period, warmed by indignation against the Yankees, the pride of victory and nationalist exaltation.) (Fornet, 2002: 32)

In other words, in terms of wider significance, the Palabras can be read as a product of, and response to, an era of siege - a heady mixture of national euphoria, national security threats and the economic threat of a complete US embargo. ${ }^{5}$

The filmmaker Julio García Espinosa, commenting in the late twentieth century, similarly described the Palabras in the context of the general political climate of siege, underlining the almost haphazard way in which culture, in the shape of the film PM, was appropriated and politicised in order to discredit the Revolution:

La contradicción fundamental no era con el comunismo o el socialismo, era con la independencia del país .... En esos 60, en esos primeros años de los 60 , se comenzó a desbrozar el camino. En esos primeros años el país envió una luz al mundo. Desde esos primeros años, los portadores de la dependencia trataron de apagarla. Tocó a la cultura afrontar uno de sus primeros soplos. Un documental fue el pretexto para hablar de una libertad abstracta. Un documental que nadie se propuso prohibirlo sin aplazarlo. (The fundamental contradiction was not with communism or socialism, it was with national independence. In that decade, those first years of the 1960s, the path began to be cleared. In those first years, the country sent a light out across the world. From those first years, the bearers of dependency tried to blow out that light. One of their first breaths touched cultural life. A documentary became the pretext to talk about absolute

5 The concept of the Revolution under real or perceived siege has recently been extensively explored, with reference to the consequences for the cultural and intellectual fields, in Navarro (2006). 
freedom. A documentary that was never intended to be banned, but rather postponed.) (Codina, 2003: 76)

In this context, and for the informed reader, García Espinosa suggested, Castro's formula 'Dentro/Contra' referred not to aesthetic dogmatism but to political independence.

However, it can also be argued that the speech drew upon, and in turn contributed to, not only the development of political and ideological positions, but also debates on social positions and behaviour in the new Cuba. In particular, and given the range of ways in which ordinary Cubans could at that time participate in constructing the future and thereby publicly demonstrate their loyalty to the Revolution, the theme of individual contribution to national development and independence also underpins and informs the atmosphere in which the Palabras were delivered.

In terms of socio-cultural policy, the Literacy Campaign is a key to understanding the motivational function of the Palabras, and the vulnerability that some writers and intellectuals may have perceived for themselves. With the emphasis on practical action at a popular level, mass participation in a variety of modes was crucial to national development: participation in the original insurrection, in the self-defence militias of 1959-1961 or in the Literacy Campaign were clearly marked as routes and demonstrations of cubanía. By implication, failure to follow these routes of active and externalised participation and public service - to follow instead the traditionally distanced, interiorised and reflective role of the intellectual-might lead one to doubt one's own patriotism or revolutionary credentials, or perhaps have them laid open to doubt. The speech also built on the informal and formal discussions that had taken place between intellectuals and political and cultural leadership at the two previous Biblioteca Nacional meetings. Importantly, as the last of a series of three meetings, and as the only published transcript from them, it moved the discussion forward by establishing an agenda for revolutionary cultural policy.

\section{The Speech}

Castro began by stating, using the first-person plural, the limited parameters of the position of authority and expertise from which he, as both an individual and political leader, was speaking, 'No lo haremos como la persona más autorizada para hablar sobre la material' ('We shall not speak as one who has greatest authority to pronounce on the matter') (Castro, 1961b: 1), implying that he was by no means a specialist in cultural and intellectual issues, unlike the audience of intellectuals (and, implicitly, members of the $\mathrm{CNC}$ ) assembled before him. He then went on, however, to establish more clearly the differences of role and remit amongst the assembled individuals in terms of 'ustedes y nosotros' ('you and us'), and extended 'nosotros' to represent not only himself, but 'los hombres de Gobierno' ('those in government') (1961b: 1); he thus implicitly but immediately underlined the political and ideological unity to which the government successfully adhered, and differentiated this from the cultural disunity of which these meetings were evidence. It was instantly clear that political and cultural fields were at one level separate, requiring their own specialist knowledge, but also to be conceptualised in terms of a hierarchy of importance, maturity and responsibility, reinforced by the hierarchical model of evolution that he articulated:

Nosotros hemos sido agentes de esta Revolución, de la Revolución económico-social que está teniendo lugar en Cuba. A su vez esa Revolución 
económica y social tiene que producir inevitablemente también una Revolución cultural en nuestro país.

(We have been agents of this Revolution, of the socio-economic Revolution taking place in Cuba. In its turn, that economic and social Revolution must inevitably produce a cultural Revolution in our country.) (1961b: 2)

He went on to reinforce the positive nature of the changes already effected in cultural life, and to underline their force and value as a gesture of inclusion to artists in the Revolution. He recognised that outside appraisals of cultural policy (such as those offered by Sartre and C. Wright Mills) were always welcome but merely underlined the improvisatory and reactive nature of the Cuban Revolution thus far:

Nosotros no tuvimos nuestra conferencia de Yenan con los artistas y escritores cubanos durante la Revolución. En realidad, esta es una revolución que se gestó y llegó al Poder [sic] en un tiempo, puede decirse "récord". Al revés de otras revoluciones, no tenía todos los principales problemas resueltos.

(We didn't have our Yenan Conference with Cuban writers and artists during the Revolution. In reality, this is a Revolution that developed and came to Power $[$ sic $]$ in what we might call "record time". In contrast to other revolutions, the fundamental problems hadn't already been resolved.) (1961b: 4)

As a result, the Cuban Revolution was still in a period of intellectual infancy, was yet to be fully theorised and was difficult to theorise, even despite the full commitment and active participation of many, including himself: 'Nosotros que hemos tenido una participación importante en esos acontecimientos, no nos creemos teóricos ni intelectuales de las revoluciones' ('Those of us who have participated significantly in those events don't consider ourselves theorists and intellectuals of Revolutions') (1961b: 4). In a brief, simple but strident sentence, Castro made it clear that the right and ability to reflect on and theorise the Cuban Revolution needed to be earned over time, and through participation as well as reflection. He went on to attack the innate superiority inherent in the position of the traditional intellectual, firing a warning shot at all those who felt that they held a closed, infallible and inviolable moral and intellectual stance: 'debemos empezar por situarnos en la posición honrada de no presumir que sabemos más que los demás, de no presumir que hemos alcanzado todo lo que se pueda aprender' ('We should start by situating ourselves in the honourable position of not presuming that we know more than others, of not presuming that we have learnt all there is to learn') (1961b: 4).

Castro thus characterised the Revolution as a learning process in which no single person or group was an expert, but in which active participation was crucial, making an explicit link with emerging socio-cultural and educational policies designed to unite through action across social and development divides. However, and as a recurrent reminder to intellectuals to understand their place in the wider context, he expressed astonishment at the reaction of various members of the group, and their continued and vocal concern for artistic freedom at a time when national security was being threatened. This time he employed the first-person plural to refer to the Cuban nation, thus inserting artists and intellectuals within the greater group, the nation, and reminding them of their patriotic duty:

Cuál debe ser hoy la primera preocupación de todo ciudadano? La preocupación de que la Revolución vaya a desbordar sus medidas, de 
que la Revolución vaya a asfixiar el arte, de que la Revolución vaya a asfixiar el genio creador de nuestros ciudadanos, o la preocupación de todos no ha de ser la Revolución misma?

(What should be the greatest concern of every citizen today? That the Revolution is going to overstep its limit, suffocate art, suffocate the creative genius of our citizens? Should the greatest concern of all of us not be the Revolution itself?) (1961b: 5)

As the meetings had been called in response to fears of censorship, the question of freedom of artistic expression was then analysed, with Castro making a clear distinction between freedom of form and freedom of content, the latter being the essential area of concern to those assembled. At the same time, however, he made it clear that any discussion of absolute freedom of expression was raised precisely by those artists and intellectuals who were predisposed to expect and anticipate repression and prohibition:

Nos parece que algunos compañeros defienden ese punto de vista. Quizás por temor a eso que estimaron prohibiciones, regulaciones, limitaciones, reglas, autoridades, para decidir sobre la cuestión.

(It appears to us that some artists defend that point of view. Perhaps [they do so] out of fear of what they judged to be prohibitions, regulations, limitations, rules, authorities, all making decisions about culture.) (1961b: 6)

In a passage that created an opposition between self-confidence and mistrust, the rough definition of the revolutionary intellectual was traced, with Castro pressing intellectuals to commit to a position, within or against, and therefore to leave behind the middleground, the terrain of doubt and suspicion, that seemed to be afflicting many of them. ${ }^{6}$

In an effort to draw out the subtleties of the definition, especially at a time when many diverse definitions co-existed, Castro went on to describe how exactly some members of the assembled group might feel threatened by the Revolution, and attempts to find a place and strategy for them within the Revolution. Just as there existed those who had established their commitment as revolutionaries, he said, and those who had established their unequivocal lack of commitment, there was also a third group who, although being accomplished artists and 'hombres honestos' ('honest men') (1961b: 7), had been taken aback by the radical and swift progress of the Revolution, and were unsure as to their position within it (these he clearly distinguished from artists in the capitalist world who were little concerned with ideology and morality). These uncertain figures, then, although honourable in their own ways, could only become true revolutionaries when they achieved true altruism by prioritising the needs of the people before their own, and seeing the world through their eyes: 'Si a los revolucionarios nos preguntan qué es lo que más nos importa, nosotros diremos el pueblo y siempre diremos el pueblo' ('If as revolutionaries we're asked what is most important to us, we shall answer "the people" and we shall always answer "the people"') (1961b: 8). It was these middleground individuals, then, who required and deserved attention and orientation from

6 Given the importance of the situational context in which the speech was delivered, it is important to note also any sections that received applause from the audience, as indicated in the Spanish text. These comments, on the need for artists and intellectuals to take a stand, elicited applause. 
the cultural and political leadership, beset as they were by their lack of harmonisation with emerging revolutionary ideology. However, and significantly, they required and deserved attention and orientation to ensure that they remained true to their beliefs and forms of expression, but only as long as these fell broadly 'dentro de la Revolución' (within the Revolution) (1961b: 10). If their ideas were perceived as running counter to the Revolution, they did not have a place within it, as it represented the interests of the nation at large and thus claimed the ultimate right to exist over any individual or group. To reinforce the point, and as Kapcia indicates (2005: 133-134), the oft-quoted formula can be read not as saying that 'if you are not clearly with us, according to a strict definition of art and culture within the Revolution (the 'Dentro/Fuera' formula), you are against us', but, rather, 'unless you are clearly against us, we will assume that you are with us in your own individual way'. ${ }^{7}$

What is less clear from this section of the Palabras, and what remains the essence of the question, is how the equation 'Dentro/Contra' addressed the traditional role of the intellectual and artist as free thinker and critical conscience. Castro underlined the role of cultural practitioners as being to offer the people 'una vida mejor en el orden cultural' ('a better cultural life') (Castro, 1961b: 11), just as the political leadership was providing material improvements. His recommendation and advice were spoken with conviction but necessarily ambiguous in their inclusiveness:

\begin{abstract}
Hay que esforzarse en todas las manifestaciones por llegar al pueblo, pero a su vez hay que hacer todo lo que esté al alcance de nuestras manos para que el pueblo pueda comprender cada vez más y mejor. Creo que ese principio no contradice las aspiraciones de ningún artista; y mucho menos si se tiene en cuenta que los hombres deben crear para sus contemporaneous.

(We must strive in all artistic representation to reach the people, but we must also do everything within our reach to ensure that the people grow in understanding and knowledge. I don't think this principle contradicts the aspirations of any artists; and much less so if we bear in mind that men should be creating for their contemporaries) (1961b: 12)
\end{abstract}

The assembled group was thus removed from its conventional distant and critical role and recast in a more participatory mode as the facilitator of cultural practice across the nation.

Now that the potential trustworthiness and the central role of artists and intellectuals had been established, and the case had been made that there were diverse individual ways of contributing to the Revolution and thus being included within it, Castro assumed a more explicit position of mediator between the CNC and the assembled individuals. Here again, he attempted to defuse fears and concerns by reassuring the assembly that the leaders of the $\mathrm{CNC}$ shared their same values and aspirations, and that the role of the CNC had been approved and supported itself by the political leadership: 'Es un deber de la Revolución y del Gobierno Revolucionario contar con un órgano altamente calificado que estimule, fomente, desarrolle y oriente, sí, oriente ese espíritu

7 Kapcia indicates that this more inclusive interpretation of 'Dentro/Contra' contributed to establishing an 'argumentalist' modus operandi for revolutionary processes (2000: 254-255); also of note, however, is its relevance to the construction of psycho-social and behavioural paradigms within the Revolution: see Fagen (1969) and Medin (1990). 
creador' ('It is the duty of the Revolution and of the Revolutionary Government to rely on a highly qualified institution to stimulate, promote, develop and orient, yes, orient that creative spirit') (1961b: 13-14). Using the analogy of a traffic police officer, judge, or miliciano [member of the militia] who acts to promote the safety and well-being of society at large, he, however, made it abundantly clear that the CNC exercised its authority appropriately and ethically, and in line with the state, and that any fear of these forms of authority was irrational and illogical. All of these agents of authority, however, were symptoms of an incomplete stage of socialism, the ultimate aim being that they would one day be unnecessary. This utopian vision (as idealistic as it may seem today) nevertheless obliges us to reconsider interpretations of Cuban revolutionary cultural policy in the 1960 s as essentially autocratic and authoritarian, advocating as it did a potential future where state control would be unnecessary.

By way of evidence, Castro listed a number of initiatives already implemented by the CNC that had improved the material and working conditions of writers and artists. Any attitude based on fear and suspicion of the CNC, then, was one that consciously or unconsciously ignored and neglected the reality of its achievements thus far, and that sought to undermine its efforts. In relation to the film $P M$, he stated, he fully trusted the opinions of those who had seen it and commented on it - President Dorticós and some members of the $\mathrm{CNC}$ - and, again, the mediatory function of the speech came to the fore here. Although the government had the legal right to regulate artistic production, he stated, he recognised that the procedures used were arguably not the most effective, nor even was the final decision necessarily the right one: but again, with the interests of the people uppermost, cinema could be a powerful instrument of influence and must therefore be managed carefully.

Castro then went on to pose the question: what to make, then, of the decision of the CNC and the reaction of the makers of PM? This section of the speech attempted to understand the reactions of all involved, to re-establish the trust and confidence of intellectuals concerned by the PM decision, but, most crucially, to underline the subjective, sometimes emotional, often passionate and inevitably conflictive reactions that underlay this period of revolutionary change. Nobody was perfect, he stated, 'incluso no podemos pensar que seamos ajenos a pasiones' ('we cannot even think that we are beyond passions') (1961b: 17). In the case of the assembled group, he asked, not without some irony, '?Es que todos vinieron acá absolutamente despojados de pasiones y de personalismos? ¿Es que todos, absolutamente, hemos venido despojados de espíritu de grupo?' ('Did you all come here exempt from passions and personal feelings? Did we all come here absolutely exempt from group loyalties?') (17-18).

Whilst the surface message was that all those involved in the process of revolution were subjective, passionate and thus led by their individual desires and visions of revolution, the subtext indicated that the traditional role of the intellectual, as an altruistic, distanced and wise observer, was a myth that excluded the loyalties, selfinterests and passions that characterise all humans. Indeed, he continued, the discussions, conflicts and passionate arguments that had taken place at the Biblioteca Nacional were themselves proof of the freedom of artistic expression that was being debated. Given, then, that a critical stance could never be disinterested, and thus free of human emotions and individual motivations, Castro asked that criticism always be directed towards constructive ends; by way of a concrete strategy to develop a culture of constructive criticism, he announced the creation of a union and cultural magazine to create spaces and opportunities for that constructive debate, to be formalised and ratified at the forthcoming Primer Congreso Nacional de Escritores y Artistas de Cuba (First 
National Congress of Cuban Writers and Artists). Rather than complaining about and fearing censorship and political intervention, he argued, 'Ya es hora de que ustedes, organizadamente contribuyan con todo su entusiasmo a las tareas que les corresponden en la Revolución y constituyan un organismo amplio, de todos los escritores y artistas' ('The time has now come for you to contribute in an organised manner and with all your enthusiasm to the tasks that belong to you in the Revolution, and to form a broad organisation of all writers and artists') (1961b: 19).

The new association would allow both for the CNC to be more effective and, importantly, for this sector to manage its own creative practices, as long as these fell broadly within the definition of revolution. Once again, Castro made it clear that the Revolution was an inclusive church, but that its right to exist superseded all other rights, including that of artistic freedom. In return, he argued, the CNC, representing writers and artists, was channelling back to government the needs and aspirations of its constituency, planning for and requesting increased budgets, improving material and working conditions (including authors' rights), publishing infrastructures, opportunities for allowing both practitioners and public to develop culture within the Revolution, and to transport it around the world; and all this in the context of economic restrictions. One of the more imaginative ideas that had yet to take concrete shape, he stated, was to create an artists' retreat on the Isla de Pinos; this ambitious idea, however, required planning in order to work. Was this planning to be seen once again as a form of restriction on artistic freedom? In other words, the new need for institutionalisation, infrastructure, planning, 'la realidad de la planificación' ('the reality of planning') (1961b: 23) that had necessarily replaced the euphoric, inspired and creative first eighteen months, had taken the political leadership by surprise, but their political maturity and optimism prevented them from claiming impractical rights. By implication, then, and as the speech progressed, the cumulative list of implied weaknesses became greater: in contrast to their political counterparts, some artists and intellectuals were not only fearful, self-centred, destructive and pessimistic, but also impractical and immature.

In addition, the sites of decision-making had changed rapidly and frequently over this brief and intense period, leading to overlaps and conflicts from the start, to disagreements and diversity regarding what revolutionary culture should be and who should be responsible for adapting it to new political and social visions. Here we find perhaps the most neglected, but also most significant, section of the text, where Castro articulated his vision of culture within the Revolution most unequivocally, and where the foundations of tensions in years to come can be discerned. He invited the assembled group to meet once again with the government, whoever that might comprise, in five to ten years' time, 'cuando haya adquirido la cultura el extraordinario desarrollo que aspiramos a que alcance cuando salgan los primeros frutos del plan de academias y de escuelas que hay actualmente' ('When culture has acquired the extraordinary level of development that we aspire for it to have, when the academies and schools we have today bear their first fruit') (1961b: 24). It was here that the overlap between the two meanings of cultura, as art and as education, and their joint intrinsic role in Cuba's development, became most evident: in the coming to fruition of new generations of revolutionary artists and writers. In their current early stages, he indicated, the aim of these programmes was to create aficionados [amateur performers], to cultivate an essentially passive taste and a knowledge base amongst the people. However, with optimism and effort, he stressed, these initiatives would ultimately 'comenzar a descubrir en el pueblo los talentos y convertir al pueblo actor en creador, porque en definitiva el pueblo es el gran creador' ('begin to discover talents in the people and turn the people as 
an actor into a creator, because ultimately the people are the great creator') (1961b: 25). They would, in other words, create active participants in culture, rescuing the talents that had been neglected through underdevelopment, social segregation and reactionary social structures. With a strong and unequivocal emphasis on egalitarianism as equality of ability as well as rights, he used his own Jesuit education as an example: 'Muchas veces he puesto como ejemplo el hecho de que en el lugar donde yo nací entre unos mil niños fui el único que pudo estudiar una carrera universitaria, mal estudiada por cierto' ('Many times I've used as an example the fact that in the place where I was born, amongst 1,000 children, I was the only one who was able to study for a university degree, and study badly at that) (1961b: 25).

Stressing several times the exceptional nature of the opportunity afforded to him, he proceeded to reveal the mechanisms upon which this opportunity was based, and urged the assembled group to consider the conditions of their own status:

‘¿Por qué? Ah, porque era el único entre mil a quien le podían pagar el colegio privado para que estudiara. Ahora, ¿por eso me voy a creer que yo era el más apto y el más inteligente entre los mil? Yo creo que somos un producto de selección, pero no tanto natural como social ... Y el que se crea artista tiene que pensar que por ahí se pueden haber quedado sin ser artistas muchos mejores que él. Si no admitimos esto estaríamos fuera de la realidad. Nosotros somos privilegiados entre otras cosas porque no nacimos hijos del carretero.

(Why? Ah, because I was the only one in a thousand who could have his fees paid so he could study. Now, is that a reason for me to believe that I was the best and the most intelligent of those thousand children? I believe we are a product of selection, not natural selection but social selection ... Whoever believes himself to be an artist should consider the fact that many who were better artists than him remained behind without fulfilling their potential. If we don't accept that, we are out of touch with reality. We are privileged, amongst other things, because we weren't born the sons of carters.) (1961b: 26)

Underlining the wasted talent, to which he referred not in terms of intellectual or educational achievement but as raw inteligencias [intelligence], the implication was clear: that these people too had the ability to become the intellectuals of tomorrow, and that this stage of the Revolution would provide that right as a priority through the system of instructores de arte [cultural teachers], charged with identifying talent and vocation throughout the country, and especially in underdeveloped rural areas. In the cultural practices that Castro listed here by way of evidence of the cultural development work already under way-dance, music, theatre - there was no mention of literature despite sustained reference in the speech to the Literacy Campaign. ${ }^{8}$

With this snapshot of the utopian future already under construction, Castro articulated a vision of culture and revolution in which current generations of artists

8 Possible reasons for the differential treatment in democratisation initiatives of the 1960s are currently being explored by the author and her co-researcher in a large-scale project on the interaction of literature and politics in revolutionary Cuba. Recent additions to scholarship on the differing impact of policy on various cultural forms can be found in Kapcia (2005), Fernandes (2006) and Miller (2008). 
were cast as collective heroes, morally bound to sacrifice their own past or present individual socio-cultural status and development in order to participate with their skills and knowledge in the collective socio-cultural project of the future:

\begin{abstract}
¿Quién no cambiaría lo suyo, quién no sacrificaría lo suyo por ese futuro? y quién que tenga sensibilidad artística no tiene la disposición del combatiente que muere en una batalla, sabiendo que él muere, que él deja de existir físicamente para abonar con su sangre el camino del triunfo de sus semejantes, de su pueblo?

(Who wouldn't change what they have, sacrifice what they have, for that future? And anyone with any feeling for art has the disposition of a combatant who gives up his physical existence in order to fertilise with his blood the triumphant path of his peers, of his people.) (1961b: 29)
\end{abstract}

The language in this, also much-quoted, section of the speech anticipated the language and themes articulated in Ernesto Guevara's 1965 essay 'El socialismo y el hombre en Cuba' ('Man and socialism in Cuba', Guevara, 1965), most notably the metaphor of the bloody path to be travelled towards communism. Indeed, many of the core values behind the vision of the 'good citizen' that were articulated in the Palabras-heroism, participation, self-sacrifice, future-orientation, self-evaluation - found strong resonances in Guevara's formulation of the 'New Man'.

Drawing parallels between the assembled group and their counterparts in the political vanguard, Castro focused on the extraordinary nature of this first generation of revolutionaries, diverse but bound by the same call for heroic self-sacrifice in service of future benefit: 'La generación venidera será mejor que la nuestra, pero nosotros seremos los que habremos hecho posible esa generación mejor. Nosotros seremos forjadores de esa generación futura' ('The next generation will be better than ours, but we will be the ones who have made possible that better generation. We will be the ones that forge that future generation') (Castro, 1961b: 30). At his most persuasive as the speech drew to a close, Castro framed the task facing this first generation in appealing terms: Who would not wish to answer this call to heroism? Who would not wish to participate in the realisation of what has until now been only the dream and theory of revolution across the ages? With the chance to participate, to be testigos presenciales [eyewitnesses] of a transcendent moment in world history, came the chance to reframe privilege not as the elitism of the past but 'por estar viviendo en medio de una Revolución' ('because of our living in the midst of a Revolution') (1961b: 30), the most important historical event for Latin America since Independence. Herein would lie the principal role of this generation, and their route to posterity, as the witnesses and chroniclers of history-in-the-making; but, he stressed, alongside those who really had a story to tell - the 106-year-old former slave who had just enrolled on the Literacy Campaign and who had, in principle, the same rights and ability to narrate her experiences through literature. He ended the speech by urging tolerance and unity, by calling for trust and cooperation with cultural institutions:

A lo que hay que temerle no es a ese supuesto juez autoritario, verdugo de la cultura, imaginario, que hemos elaborado aquí. !Teman a otros jueces mucho más temibles, teman a los jueces de la posteridad, teman a las generaciones futuras que serán, al fin y al cabo, las encargadas de decir la última palabra! 
(What you should fear is not that alleged authoritarian judge, that imaginary executioner of culture that we have depicted here. Fear other judges who inspire far greater fear, fear the judges of posterity, fear the future generations who will be, when all's said and done, those who are responsible for saying the last word!) (1961b: 32)

Through a multi-layered and complex speech, Castro attempted to persuade the assembled audience that their fears of repression were ungrounded, that there existed a space for their contribution to the collective project, that their rights must be accompanied by responsibilities, and that the new era of planning was as necessary in cultural life as in any other sphere of revolutionary policy. At the same time as he reassured and allayed fears, however, he made it clear that the majority had priority over any single individual or group, and that a new era of egalitarianism had dawned where social and economic privilege no longer existed, and in which those who formerly held such privilege faced a stark choice: to contribute or leave. Equally importantly, however, alongside these pragmatic and responsive contexts, the Palabras served the central function of re-semanticising the cultural lexis and transforming the cultural landscape.

In this process of recoding the meaning of culture, the speech thus threw up several tensions, frustrations and contradictions regarding the position of the writer and intellectual in the new revolutionary society that it is useful to explore in further depth. As indicated earlier, the Palabras, deliberately or otherwise, were remarkably silent on the position of literature in the context of its relationship with policies of cultural massification and democratisation. In the absence of clearer indications about the implications for existing writers, the speech was open to some uncomfortable, if not threatening, interpretations: that, once literate, anyone in principle had not only the right, but, more significantly, the ability to be a writer; and that there existed a massive resource in the form of untold stories and experiences that existing writers, having developed under conditions of privilege and inequality, would clearly never have, hence his characterisation of the assembled group as chroniclers of external events, narrators of other people's lives, educators of future literary talents. This left existing established writers in an unclear and possibly damaging position, where the conditions of their previous and current prestige were no longer a valid currency. Their privilege and prestige had been reframed as a future of self-sacrifice rather than self-expression.

In this context of radicalisation, then, where national self-defence and international relations had become central and where a profound development programme was underway, why should a relatively small group of writers and artists be afraid of losing their rights? As much as the speech offered a conciliatory perspective, there was also evidence of an underlying impatience with, and even some gentle mocking of, the group as excessively paranoid and introverted, more preoccupied with individual status and reflexion than with collective progress and action. Interestingly, the speech also offered an early mention of a strand of thought that was later expressed much more stridently in the Congreso de Educación y Cultura (Congress of Education and Culture) of 1971 - that of the people as the great actor of the Revolution, the ultimate conciencia critica [critical conscience] which, in this case, decided the worth of cultural production. In the subsequent period, many of the gentle criticisms of the group that Castro noted and expressed in the Palabras, echoed some years later in the 'pecado original' ('original sin') of Guevara's 1965 essay, were distorted, intensified and used as a basis for the marginalisation, exclusion and mistreatment of individual writers, artists and intellectuals throughout the quinquenio gris [grey five years] and beyond, and have only 
recently been reassessed in the 'Encuentros' of 2007: the lack of participation in armed combat during the insurrection; residence abroad during the period of the rebellion, not even having been testigos presenciales; the expression of potentially deviant ideas not only regarding sexuality and religious belief, but also personal animosities and power struggles.

On the other hand, if the fears articulated by the group were essentially petty and insignificant in the context of the much more urgent concerns facing the country, why should the political and cultural leadership feel it necessary to attend to these fears in a series of extraordinary special meetings? Castro's impatience with the assembled group was balanced by the implicit recognition that Cuban artists and intellectuals had to be kept 'onside' because they were an important symbol of national and international prestige, of participation in an international cultural economy (Casanova, 2004: 81). Whilst the utopian vision of an entire island of writers and artists was yet unachieved, the existing cultural capital must be preserved, protected, nurtured and guided. The ensuing series of contradictions - between the need to preserve existing cultural prestige and the need to transform it in line with more radical developments in society, politics and culture, and between national and international literary spaces - is one that is unresolved to this day.

With hindsight, then, and especially through the optic of the caso Padilla [Padilla Affair] and the subsequent quinquenio gris, the Palabras have been read as the first sign that politics and culture would have not only a tense relationship, but one in which all aesthetic and formal questions, supposedly the core of any artist's expertise and vocation, would be subsumed to political priorities, and would be regulated by an all-seeing and all-powerful state. Propaganda and didacticism: there is no shortage of terms to describe the expectation and fear that Cuban culture would operate from the top downwards and blindly follow the precepts of Soviet socialist realism. This assumption is predicated on several others: first, that true artists and intellectuals are not influenced by power relations, social and economic circumstances and political manoeuvrings; second, that art must be unique and formally complex in order to be successful (wherever its success lies, itself very debatable); third, that art must be resistant, and run counter to political discourses in order to be effective and true to itself. The Palabras thus responded not only to the immediate circumstances of tension and suspicion, but also attempted to address more conceptual concerns about the new roles and responsibilities of the artist and intellectual in an island in revolution, in a postcolonial context, on the periphery of an international cultural economy.

\section{Conclusions}

In conclusion, and to return briefly to the key extract that has so influenced readings of the Palabras, 'Dentro/Contra' were necessarily unstable concepts that, far from establishing the rigid parameters of the permissible in cultural practice over nearly 50 years, are unresolved to this day. Although it may be possible to use them as cornerstones to examine moments of cultural debate, it is perhaps more useful to view them as dynamic and dialogic elements, mutually dependent and always shifting. As Fornet expresses it:

O sea que el "todo" no es una posesión vitalicia sino un espacio conflictivo que hay que reconquistar día tras día, no haciendo concesiones a 
la burocracia pero tampoco cediendo, por capricho, a la tentación a la irresponsabilidad. Sea como fuere, lo cierto es que un movimiento cultural como el nuestro ... ha podido desarrollarse casi siempre de acuerdo con su propia dinámica y en un clima de libertad envidiable.

(In other words, the 'everything' is not a lifelong possession but a contested space which must be reconquered day after day, by neither conceding to bureaucracy nor, more capriciously, to the temptation to be irresponsible. At all costs, what is certain is that our cultural movement has nearly always been able to develop according to its own dynamics and in a climate of enviable freedom.) (Fornet, 2002: 36).

More importantly, however, the other parts of the text that have been somewhat neglected by commentators on Cuban cultural questions placed the emphasis clearly on cultural education and development, on egalitarianism and thus on the potential for freedom and meritocracy through cultural participation. An idealistic formulation, perhaps, but one that offered a profoundly affirmative view of the role that culture could and would play in the Revolution. As such, as much as the Palabras might have revealed some impatience on the part of Castro that, in the midst of huge shifts in the Revolution's national and international development, intellectuals should be worrying about such peripheral factors as freedom of artistic expression and the role of the writer, the June 1961 meetings of prominent members of the political and leadership with intellectuals, and Castro's attempts to define as broadly as possible the particular contributions of artists and intellectuals to the Revolution, also underlined the importance of their new role within the wider context of socio-economic change. Seen in a wider context, then, the speech can be seen to have been advocating an essentially inclusive and affirmative vision: that as long as they did not knowingly work to damage the Revolution or the people, artists and intellectuals were at liberty to find their own ways of contributing to the collective national project. The Palabras thus also suggested a more positive reading: that the meetings were prompted as much by many artists' and intellectuals' collective sense of responsibility, enthusiasm and willingness to contribute to the Revolution as they were by their more self-interested fears of censorship, regulation or repression.

\section{References}

Abreu Arcia, A. (2007) Los juegos de la Escritura o la (re)escritura de la Historia. Casa de las Américas: Havana.

Casal, L. (1971) 'Literature and Society', in C. Mesa-Lago (ed.) Revolutionary Change in Cuba. University of Pittsburgh Press: Pittsburgh, 447-469.

Casanova, P. (2004) The World Republic of Letters (trans. M.B. DeBevoise). Harvard University Press: Cambridge, London.

Castro, F. (1961a) Palabras a los Intelectuales. Consejo Nacional de Cultura: Havana.

Castro, F. (1961b) Palabras a los intelectuales [WWW document]. URL http://www.min. cult.cu/historia/palabras.doc [accessed 24 March 2009].

Castro, F. (1961c) Word to the Intellectuals [WWW document]. URL http://lanic.utexas.edu/ project/castro/db/1961/19610630.html [accessed 24 March 2009].

Codina, N. (ed.) (2003) Siglo Pasado. Editorial Capiro/Ediciones Unión: Santa Clara, Havana.

Dopico Black, G. (1989) 'The Limits of Expression: Intellectual Freedom in Postrevolutionary Cuba'. Cuban Studies 19: 107-142.

Fagen, R. (1969) The Transformation of Political Culture in Cuba. Stanford University Press: Stanford, CA. 
Fernandes, S. (2006) Cuba Represent! Cuban Arts, State Power, and the Making of New Revolutionary Cultures. Duke University Press: Durham, NC and London.

Fornet, A. (2002) La Coartada Perpetua. Siglo Veintiuno Editores: Mexico.

Franco, J. (2002) The Decline and Fall of the Lettered City: Latin America in the Cold War. Harvard University Press: Cambridge, London.

Guevara, E. (1965) 'El socialismo y el hombre en Cuba'. Verde Olivo, 14 November, $15-1868$.

Kapcia, A. (2000) Cuba: Island of Dreams. Berg: Oxford, New York.

Kapcia, A. (2005) Havana: The Making of Cuban Culture. Berg: Oxford, New York.

Medin, T. (1990) Cuba: The Shaping of Revolutionary Consciousness. Lynne Rienner: Boulder, CO.

Miller, N. (2008) 'A Revolutionary Modernity: The Cultural Policy of the Cuban Revolution'. Journal of Latin American Studies 40: 675-696.

Navarro, D. (2006) 'In media res publicas: sobre los intelectuales y la esfera pública cubana', in D. Navarro (ed.) Las Causas de las Cosas. Editorial Letras Cubanas: Havana.

Pogolotti, G. (2006) Polémicas Culturales de los Sesenta (selección y prólogo). Editorial Letras Cubanas: Havana.

La Política Cultural del Periodo Revolucionario: Memoria y Reflexión. Ciclo de Conferencias Organizado por el Centro Teórico-cultural Criterios (Primera Parte) (2007.) Centro Teórico-Cultural Criterios (Colección Criterios): Havana.

Serra, A. (2007) The 'New Man' in Cuba: Culture and Identity in the Revolution. University Press of Florida: Florida.

Weiss, J. (1985) 'The emergence of popular culture', in S. Halebsky, J. Kirk (eds.) Cuba: Twenty-Five Years of Revolution, 1959-1984. Praeger: New York, Westport, London, $117-133$.

\section{Films}

PM, 1961. Film. Directed by Sabá CABRERA INFANTE and Orlando JIMÉNEZ-LEAL. Cuba: ICAIC. 